DOI: $10.31774 / 2222-1816-2020-3-38-51$

\title{
А. А. Новиков
}

Всероссийский научно-исследовательский институт орошаемого земледелия, Волгоград, Российская Федерация

\section{ВЛИЯНИЕ ВОДООБЕСПЕЧЕННОСТИ НА ФОРМИРОВАНИЕ УРОЖАЙНОСТИ И ВОДОПОТРЕБЛЕНИЕ КАРТОФЕЛЯ НА ЧЕРНОЗЕМНЫХ ПОЧВАХ ВОЛГОГРАДСКОЙ ОБЛАСТИ}

Цель: определить влияние водообеспеченности на особенности роста, развития, урожайность и водопотребление картофеля весеннего срока посадки. Материалы $\boldsymbol{u}$ методы: исследования проводились на черноземных почвах Волгоградской области. Изучалось влияние водообеспеченности на рост, развитие, урожайность и водопотребление картофеля. Различная водообеспеченность создавалась изменением расчетной поливной и оросительной нормы (контроль) путем увеличения на $20 \%$ и снижения на 20 и 40 \%. Закладка опытов производилась по Б. А. Доспехову (1985), наблюдения и исследования осуществлялись по методике Всероссийского научно-исследовательского института орошаемого земледелия В. Н. Плешакова (1983). Математическая обработка данных опыта производилась с применением Microsoft Office Excel 2007. Результаты: установлено, что под влиянием различной водообеспеченности изменились морфологические показатели: в варианте 2 растения имели большую высоту $(0,74$ м) и площадь листовой поверхности в фазе бутонизации и цветения (30,9 и 30,1 тыс. м²/га), однако более высокая водообеспеченность в варианте 2 не способствовала формированию большей абсолютно сухой массы. Урожайность товарных клубней была более высокой $(58,8$ т/га) в варианте 1 против 55,9 т/га в варианте 2. Она оказалась ниже, чем на контроле, из-за большего процента поражения клубней фитофторой, хотя разница в урожае в 2016 и 2017 гг. была в пределах НСР, а в 2015 г. была существенной - больше HCP. Выводы: уменьшение оросительной нормы на 20 \% в варианте 3 и на $40 \%$ в варианте 4 привело к снижению урожайности до 53,1 и 43,7 т/га соответственно, но при снижении оросительной нормы на 20 \% в варианте 3 урожайность снижается только на 9,7 \%, а уменьшение оросительной нормы на 40 \% приводит к снижению урожайности на 25,6 \%, т. е. можно говорить об экономии водных ресурсов на единицу продукции.

Ключевые слова: картофель; орошение; мелиорация; водообеспеченность; оросительная норма; водопотребление.

\section{A. A. Novikov}

All-Russian Research Institute of Irrigated Agriculture, Volgograd, Russian Federation

\section{WATER AVAILABILITY INFLUENCE ON YIELD AND WATER CONSUMPTION OF POTATO ON THE BLACK-EARTH SOILS OF VOLGOGRAD REGION}

Purpose: to determine the water availability impact on the growth, development, yield and water consumption characteristics of spring planted potatoes. Materials and methods: the research was conducted on chernozem soils of Volgograd region. The impact of water availability on the growth, development, yield and water consumption of potatoes was studied. Different water availability was created by changing the calculated water application rate 
and irrigation rate (control) by increasing by $20 \%$ and decreasing by 20 and $40 \%$. The experiments were laid out according to B. A. Dospekhov (1985), observations and studies were carried out according to the methodology of All-Russian Research Institute of Irrigated Agriculture named after V. N. Pleshakov (1983). Mathematical processing of experimental data was performed using Microsoft Office Excel 2007. Results: it was found that morphological indicators changed under the influence of different water availability: in option 2, the plants had the biggest height $(0.74 \mathrm{~m})$ and leaf area in the budding and flowering phase (30.9 and 30.1 thousand $\mathrm{m}^{2} / \mathrm{ha}$ ), but the higher water availability in option 2 did not contribute to the formation of a larger oven dry mass. Productivity of marketable tubers was higher $(58.8 \mathrm{t} / \mathrm{ha})$ in option 1 versus $55.9 \mathrm{t}$ per ha in option 2. It turned out to be lower than in the control, due to the higher percentage of tuber damage by phytophthora, although the difference in yield in 2016 and 2017 was within the least significant difference, and in 2015 was significant - more than the LSD. Conclusions: a decrease in the irrigation rate by $20 \%$ in option 3 and by $40 \%$ in option 4 led to a decrease in yield to 53.1 and $43.7 \mathrm{t} / \mathrm{ha}$, respectively, but when the irrigation rate decreases by $20 \%$ in option 3, the yield decreases only $9.7 \%$, and a decrease in irrigation rate by $40 \%$ leads to a decrease in productivity by $25.6 \%$, i. e. one can talk about water resources saving per unit of output.

Key words: potatoes; irrigation; land reclamation; water availability; irrigation rate; water consumption.

Введение. Орошение является одним из основных факторов получения стабильных урожаев сельскохозяйственных культур и обеспечения устойчивого развития АПК России $[1,2]$.

Расширение площадей орошаемого земледелия в России ограничивается наличием водных ресурсов. Хотя на Россию приходится почти 50 \% водных ресурсов, в экономике страны используется только около 65 км $^{3}$ воды, в т. ч. на АПК приходится около 8,8 км³ $[3,4]$. Этот объем значительно уменьшился по сравнению с 1980 г., когда мелиорация земель имела самое широкое развитие в России и водопользование для орошения и сельхозводоснабжения составляло 23 км³. Практически исчерпаны водные ресурсы р. Дон, Терек, Кубань. Ощущается недостаток водных ресурсов на р. Волге [5]. Поэтому рациональное использование водных ресурсов возможно за счет нормирования и повышения эффективности использования водных ресурсов в орошаемом земледелии [6], повышения плодородия почвы $[7,8]$, разработки новой техники и технологий орошения, управления процессами формирования продуктивности орошаемых агробиоценозов.

Основные водные ресурсы имеются в Сибири, но там агроклиматические условия не позволяют расширять площади орошаемых земель, а низкая 
Научный журнал Российского НИИ проблем мелиорации, № 3(39), 2020 г., [38-51]

биопродуктивность земель снижает эффективность их использования по сравнению, например, с югом России [9]. Поэтому в связи с возрастающим дефицитом водных ресурсов, используемых в орошаемом земледелии, все актуальнее становится вопрос разработки ресурсосберегающих технологий орошения, способных уменышить водоемкость потребления воды в АПК, в данном случае расход воды на производство единицы растениеводческой продукции [10]. Это возможно достичь двумя путями. Во-первых, путем значительного увеличения урожайности, что уменьшит расходы воды на $1 \mathrm{~T}$ урожая, или же, во-вторых, изучением и подбором режима орошения, при котором количество используемой воды уменьшается в большей степени, чем урожайность, и этим достигается экономия воды на единицу урожая.

Цель исследований - определить влияние водообеспеченности на особенности роста, развития, урожайность и водопотребление картофеля весеннего срока посадки.

Материалы и методы. В наших исследованиях различная степень водообеспеченности растений в течение вегетации осуществлялась путем изменения в вариантах опыта расчетной поливной нормы 1,0 $m(\mathrm{~K})$ в слое почвы 0,6 м в большую на $20 \%$ до $1,2 m$ или в меньшие стороны на $20 \%$ $(0,8 m)$ и на $40 \%(0,6 m)$. Схемой опыта было предусмотрено пять вариантов для изучения влияния различной водообеспеченности на рост, развитие, урожайность и водопотребление картофеля весеннего срока посадки: вариант 1 - поливная норма 1,0 $m$ (контроль $(\mathrm{K})$ ); вариант 2 - поливная норма 1,2 $m$; вариант 3 - поливная норма $0,8 m$; вариант 4 - поливная норма 0,6 m; вариант 5 - без орошения (для определения прибавки урожая от орошения).

Исследования проводились на черноземах Волгоградской области в 2015-2017 гг. в КФХ Мурасова Новониколаевского района. Почвы представлены черноземами обыкновенными среднемощными среднегумусными, сформированными на лессовидных тяжелых суглинках. Глинистых частиц в слое почвы 0-1,0 м больше 60 \%. Сильное вскипание отмечается с глубины 0,30-0,40 м. Почвы характеризуются средним содержанием лег- 
когидролизуемого азота в пахотном слое 0-0,3 м - 2,1-5,3 мг/100 г почвы. Подвижными формами фосфора в пахотном слое почвы средне обеспечены (1,6-3,3 мг/100 г почвы). Содержание калия в почвах повышенное 32-51 мг/100 г почвы, pH 6,5-7,0.

Сумма температур выше $10{ }^{\circ} \mathrm{C}$ составляет $2800-3000{ }^{\circ} \mathrm{C}$, среднегодовые $+5,3^{\circ} \mathrm{C}$. Продолжительность безморозного периода в среднем 150 дней. Количество осадков за год составляет 300 мм, основное количество выпадает летом. Испаряемость - 750 мм. Опытный участок относится к засушливой зоне, гидротермический коэффициент ГТК = 0,7.

В контрольном варианте поддерживался режим орошения почвы выше 80 \% НВ в расчетном слое почвы 0,6 м. В слое почвы 0,6 м НВ составляет 30,25 \% от веса абсолютно сухой почвы. Поливы проводились дождевальной машиной австрийской фирмы Bauer, размеры делянок $50 \times 120$ м,

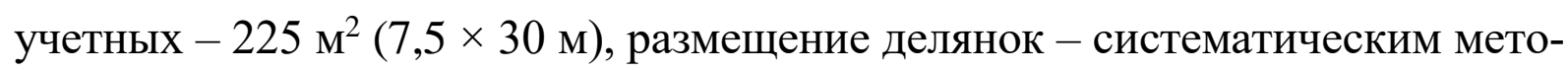
дом, повторность четырехкратная [11]. Наблюдения за ростом, развитием и урожайностью картофеля проводились по методике ВНИИОЗ [12]. Возделывали картофель в соответствии с зональными системами земледелия [13], высаживали пророщенные клубни, норма высадки 60 тыс. клубней на 1 га с шириной междурядий 0,75 м. Высаживался сорт Жуковский ранний [14].

Результаты и обсуждение. В опытах различные условия водообеспеченности картофеля создавались путем изменения расчетной поливной нормы $(1 m)$ от 0,6 $m$ до $1,2 m$, соответственно изменялась и оросительная норма. Сроки полива назначались в тот же день, что и в контрольном варианте 1, но разными поливными нормами. За годы исследований во всех вариантах кратность поливов (6,3 шт.) и продолжительность поливного сезона (71 сут) были одинаковыми, но при этом средняя поливная норма по вариантам уменьшалась с $540 \mathrm{~m}^{3} /$ га в варианте 2 до $270 \mathrm{~m}^{3} /$ га в варианте 4, соответственно изменялась оросительная норма с $3600 \mathrm{~m}^{3} /$ га в варианте 2 до $1800 \mathrm{~m}^{3} /$ га в варианте 4, т. е. в 2 раза.

Предложенная схема опыта и поливной режим позволяют изменять 
вдвое показатель обеспеченности растений водой в течение вегетации и выявлять закономерности влияния этого фактора на рост, развитие и урожайность картофеля. Так, наблюдения показали, что условия водообеспеченности оказывали различное влияние на продолжительность вегетационного периода и другие показатели роста и развития растений. Продолжительность вегетации от всходов до технологической спелости изменялась от 79 дней в варианте 2 до 73 дней в варианте 4 и 71 дня в варианте 5 (без орошения), или в процентном отношении от плюс 2,6 до минус 5,2 и минус 7,8 \% соответственно (таблица 1).

Таблица 1 - Влияние водообеспеченности на высоту растений и морфологические показатели, 2015-2017 гг.

\begin{tabular}{|c|c|c|c|c|}
\hline \multirow[b]{2}{*}{ Вариант } & \multirow[b]{2}{*}{$\begin{array}{c}\text { Вегетаци- } \\
\text { онный } \\
\text { период, сут }\end{array}$} & \multicolumn{3}{|c|}{ Максимальная } \\
\hline & & $\begin{array}{l}\text { высота } \\
\text { расте- } \\
\text { ний, м }\end{array}$ & $\begin{array}{c}\text { площадь листо- } \\
\text { вой поверхно- } \\
\text { сти, тыс. м²/га }\end{array}$ & $\begin{array}{c}\text { масса растений } \\
\text { в абсолютно сухом } \\
\text { веществе, г/м² }\end{array}$ \\
\hline Вариант 1. 1,0 m (K) & 77 & 0,69 & 30,9 & 1980 \\
\hline Вариант 2. 1,2 m & 79 & 0,74 & 30,1 & 1901 \\
\hline Вариант 3. 0,8 $\mathrm{m}$ & 75 & 0,63 & 28,7 & 1820 \\
\hline Вариант 4. 0,6 m & 73 & 0,59 & 27,0 & 1510 \\
\hline Вариант 5. Без орошения & 71 & 0,48 & 18,9 & 590 \\
\hline
\end{tabular}

Под влиянием различной водообеспеченности изменились также морфологические показатели, такие как высота растений и площадь листовой поверхности. Высота растений была больше $(0,74$ м) в варианте 2 и снижалась до 0,59 м в варианте 4 и до 0,48 м в варианте 5 без орошения. Установлена прямая связь высоты растений с водообеспеченностью, она описывается уравнением У $h=0,251 x+0,4711$ при достоверности аппроксимации $R^{2}=0,98$.

Площадь листовой поверхности картофеля достигала больших значений в вариантах 1 и 2 в фазах бутонизации и цветения (30,9 и 30,1 тыс. м²/га) и снижалась с уменьшением водообеспеченности в варианте 3 на $20 \%$ до 28,7 тыс. м²/га и в варианте 4 до 27,0 тыс. м²/га. Сравнительный анализ темпов прироста листовой поверхности позволил установить прямую связь индекса площади листовой поверхности растений с водообеспеченностью, 
она описывается уравнением $\mathrm{Y}_{s}=1,008 x+1,9862$ при достоверности аппроксимации $R^{2}=0,92$.

Наблюдения в динамике за приростом надземной массы и клубней показали, что водообеспеченность оказывает существенное влияние на прирост как надземной массы (стеблей и листьев), так и клубней. Более высокая водообеспеченность и темпы прироста в контрольном варианте 1 и в варианте 2 позволили растениям сформировать и большую абсолютно сухую массу (как надземную, так и клубней), которая к периоду спелости

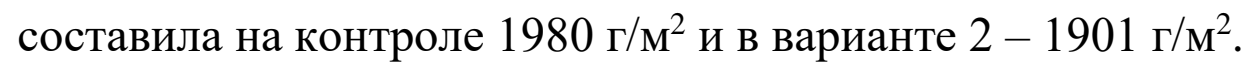

Снижение поливной нормы и водообеспеченности в вариантах 3 и 4 по сравнению с контрольным вариантом 1 также приводило к снижению абсолютно сухой массы с 1980 г/м² на контроле до 1820 и 1510 г/м² в вариантах 3 и 4. Наименьшая масса сформировалась в варианте 5 без орошения 590 г/м², что в 3,4 раза меньше, чем на контроле.

После цветения масса растений несколько снижается, например, на контроле снижается до 44 г/( м $^{2}$ сут $)$, но остается высокой до самой технологической спелости клубней. Сравнение темпов прироста в варианте 2

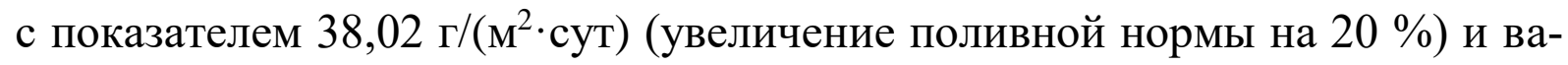
рианте 3 с показателем 42,82 г/( $\mathrm{M}^{2} \cdot$ сут) (уменьшение поливной нормы на 20 \%) показывает, что наблюдается обратная взаимосвязь, так как растения в варианте 2 из-за более высокой влажности почвы заболевают (в основном фитофторой) и не добирают часть массы растений и клубней по сравнению с контролем. Этот вывод подтверждается и результатами учета урожайности (таблица 2).

\section{Таблица 2 - Урожайность картофеля весеннего срока посадки} при различной водообеспеченности на черноземах, 2015-2017 гг.

\begin{tabular}{|c|c|c|c|c|c|c|}
\hline \multirow{2}{*}{ Вариант } & \multicolumn{4}{|c|}{ Урожайность по годам, т/га } & \multicolumn{2}{|c|}{ Отклонение от контроля } \\
\hline & 2015 & 2016 & 2017 & средняя & т/га & $\%$ \\
\hline 1 & 2 & 3 & 4 & 5 & 6 & 7 \\
\hline Вариант 1. 1,0 m (K) & 57,7 & 58,1 & 60,7 & 58,8 & 0 & 0 \\
\hline Вариант 2. 1,2 $\mathrm{m}$ & 55,4 & 56,1 & 56,4 & 55,9 & $-2,8$ & $-4,8$ \\
\hline
\end{tabular}


Продолжение таблицы 2

\begin{tabular}{|l|c|c|c|c|c|c|}
\hline \multicolumn{1}{|c|}{1} & 2 & 3 & 4 & 5 & 6 & 7 \\
\hline Вариант 3. 0,8 m & 52,2 & 52,0 & 55,2 & 53,1 & $-5,7$ & $-9,7$ \\
\hline Вариант 4. 0,6 m & 41,3 & 45,2 & 44,6 & 43,7 & $-15,1$ & $-25,6$ \\
\hline Вариант 5. Без орошения & 13,9 & 18,2 & 19,4 & 17,2 & $-41,6$ & $-70,8$ \\
\hline HCР $_{05}$, т/га & 4,7 & 3,3 & 2,8 & - & - & - \\
\hline
\end{tabular}

В среднем за годы исследований (2015-2017 гг.) более высокая урожайность 58,8 т/га клубней была в варианте 1 (контроль). В варианте 2 растения были в большей мере обеспечены водой в течение всей вегетации, однако товарная урожайность клубней составила 55,9 т/га. Она оказалась ниже, чем на контроле, из-за большего процента поражения клубней фитофторой, хотя разница в урожае в 2015 и 2016 гг. была в пределах НСР, а в 2017 г. была существенной - больше НСР.

Уменьшение поливной и оросительной нормы на $20 \%$ в варианте 3 также привело к снижению урожайности до 53,1 т/га против 58,8 т/га на контроле. Однако здесь не наблюдается прямой зависимости урожайности от водообеспеченности, так, при снижении оросительной нормы на $20 \%$ урожайность снижается только на 9,7 \%. Такая же закономерность наблюдается и при сравнении данных об урожайности в варианте 4. Уменьшение оросительной нормы на 40 \% привело к снижению урожайности на 25,6 \%, т. е. мы можем говорить об экономии водных ресурсов на единицу продукции в вариантах 3 и 4, что подтверждается данными о водопотреблении картофельного поля.

Представленные в таблице 3 данные показывают, что суммарное водопотребление изменяется в зависимости от водообеспеченности как по годам, так и в среднем за 2015-2017 гг., составляя от 2332 м³/га в варианте 5 без орошения до 4760 м³/га на контроле и до 4938 м³/га в варианте 2.

В вариантах 1-4 основная доля воды поступает к растениям с оросительной водой (от 46,6 \% в варианте $4(0,6 m)$ до 72,9 \% в варианте 2 с увеличенной нормой полива на $20 \%$ ). Оросительная норма при этом увеличивалась с $1800 \mathrm{~m}^{3} /$ га в варианте 4 до $3000 \mathrm{~m}^{3} /$ га на контроле и $3600 \mathrm{~m}^{3} /$ га 
в варианте 2. Осадки, выпадающие в период вегетации, составляют менее 10 \% от суммарного водопотребления в вариантах 1-4 и 16,51 \% в варианте без орошения.

\section{Таблица 3 - Показатели водопотребления картофеля весеннего срока посадки в зависимости от водообеспеченности в среднем 3а 2015-2017 гг.}

\begin{tabular}{|c|c|c|c|c|c|}
\hline \multirow[b]{2}{*}{ Вариант } & \multicolumn{4}{|c|}{ Суммарное водопотребление } & \multirow{2}{*}{$\begin{array}{c}\text { Коэффици- } \\
\text { ент водопо- } \\
\text { требления, } \\
\text { мT }^{3}\end{array}$} \\
\hline & $\begin{array}{c}\text { Всего, } \\
\text { м³ } / г а^{2}\end{array}$ & $\begin{array}{c}\text { Исполь- } \\
\text { зовано из } \\
\text { почвы, \% }\end{array}$ & $\begin{array}{c}\text { Ороси- } \\
\text { тельная } \\
\text { норма, \% }\end{array}$ & $\begin{array}{c}\text { Осадки, } \\
\%\end{array}$ & \\
\hline Вариант 1. 1,0 m (K) & 4760 & 28,9 & 63,0 & 8,1 & 81,0 \\
\hline Вариант 2. 1,2 m & 4938 & 19,3 & 72,9 & 7,8 & 88,3 \\
\hline Вариант 3. $0,8 \mathrm{~m}$ & 4262 & 34,7 & 56,3 & 9,0 & 80,3 \\
\hline Вариант 4. 0,6 m & 3860 & 43,4 & 46,6 & 10,0 & 88,3 \\
\hline Вариант 5. Без орошения & 2332 & 83,5 & 0,0 & 16,5 & 135,6 \\
\hline
\end{tabular}

Наблюдения показали, что использование влаги из почвы обратно пропорционально водообеспеченности: в варианте 5 без орошения доля составляет $83,5 \%$, в варианте $4-43,4 \%$, в варианте $3-34,7 \%$ против $28,9 \%$ на контроле. Увеличение поливной нормы на 20 \% в варианте 2 уменьшило поступление влаги из почвы до 19,3%.

Изменяется и эффективность использования воды на формирование единицы урожая, которая в наших исследованиях определялась по показателю коэффициента водопотребления и по показателю формирования урожая из расчета на 1000 м³/га оросительной воды.

Наименьшим коэффициент водопотребления (80,3 м³/т) был в варианте 3 при уменьшении оросительной нормы на 20 \%. На контроле он возрастал до $81,0 \mathrm{~m}^{3} /$ т, а в вариантах 2 и 4 увеличился и составил по $88,3 \mathrm{~m}^{3} /$ т. В варианте 5 без орошения эффективность использования воды из почвы и осадков была самой низкой $(135,6$ м³/T), так как почвенные запасы осеннезимнего периода были использованы растениями на формирование вегетативной массы, а в период формирования клубней осадки выпадали в малом количестве и неравномерно.

В вариантах с орошением эффективность использования ороситель- 
ной воды выражается также водоемкостью продукции, т. е. производством клубней на 1000 м³. По этому показателю картофель обеспечил большую отдачу урожая (24,3 и 22,1 т/1000 м³) в вариантах 4 и 3, в которых сокращалась оросительная норма на 40 и 20 \% соответственно. В контрольном варианте 1 этот показатель составил 19,6 т и наименьшим (15,5 т) был в варианте 2 с увеличенной на 20 \% оросительной нормой.

Приведенные выше данные показывают, что в условиях острого дефицита водных ресурсов для получения большей отдачи от используемой оросительной воды возможно снижение оросительной нормы на $20 \%$, при этом урожайность снижается на 9,7 \%, но повышается эффективность использования оросительной воды (на каждую $1000 \mathrm{~m}^{3}$ воды получено по 22,1 т/га клубней против 19,6 т/га на контроле).

Математическая обработка полученных данных позволила установить, что существует взаимосвязь между величиной урожайности и оросительной нормой (рисунок 1) с высоким коэффициентом аппроксимации $R^{2}=0,97$. Взаимосвязь выражается уравнением полинома второй степени вида: $\mathrm{У}_{\text {ор }}=-0,000003 x^{2}+0,0216 x+16,69$.

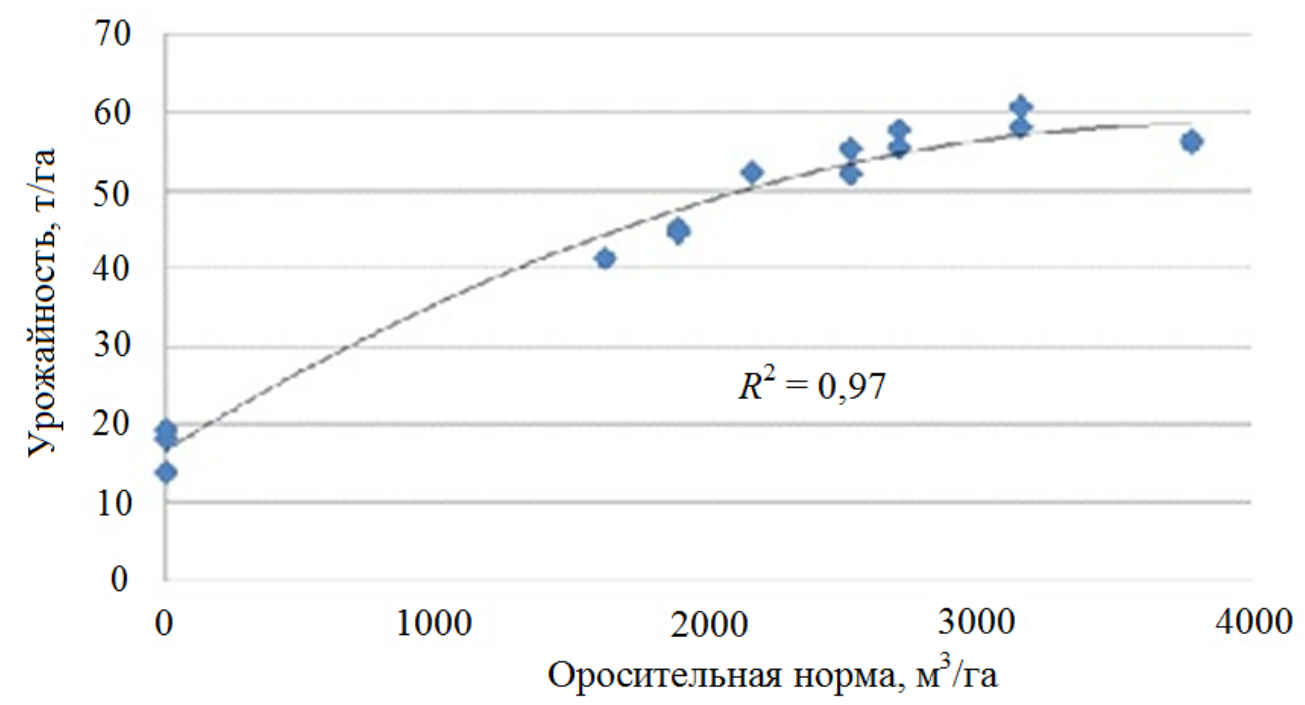
Рисунок 1 - Взаимосвязь между урожайностью и оросительной нормой
картофеля весеннего срока посадки на черноземах, 2015-2017 гг.

Математическая обработка данных позволила также установить взаимосвязь между урожайностью $\left(\mathrm{У}_{\mathrm{y}}\right)$ и величиной суммарного водопотреб- 
ления с высоким коэффициентом аппроксимации $R^{2}=0,92$, которая выражается уравнением полинома второй степени (рисунок 2):

$$
\mathrm{y}_{\mathrm{y}}=-0,000001 x^{2}+0,0259 x-34,717
$$

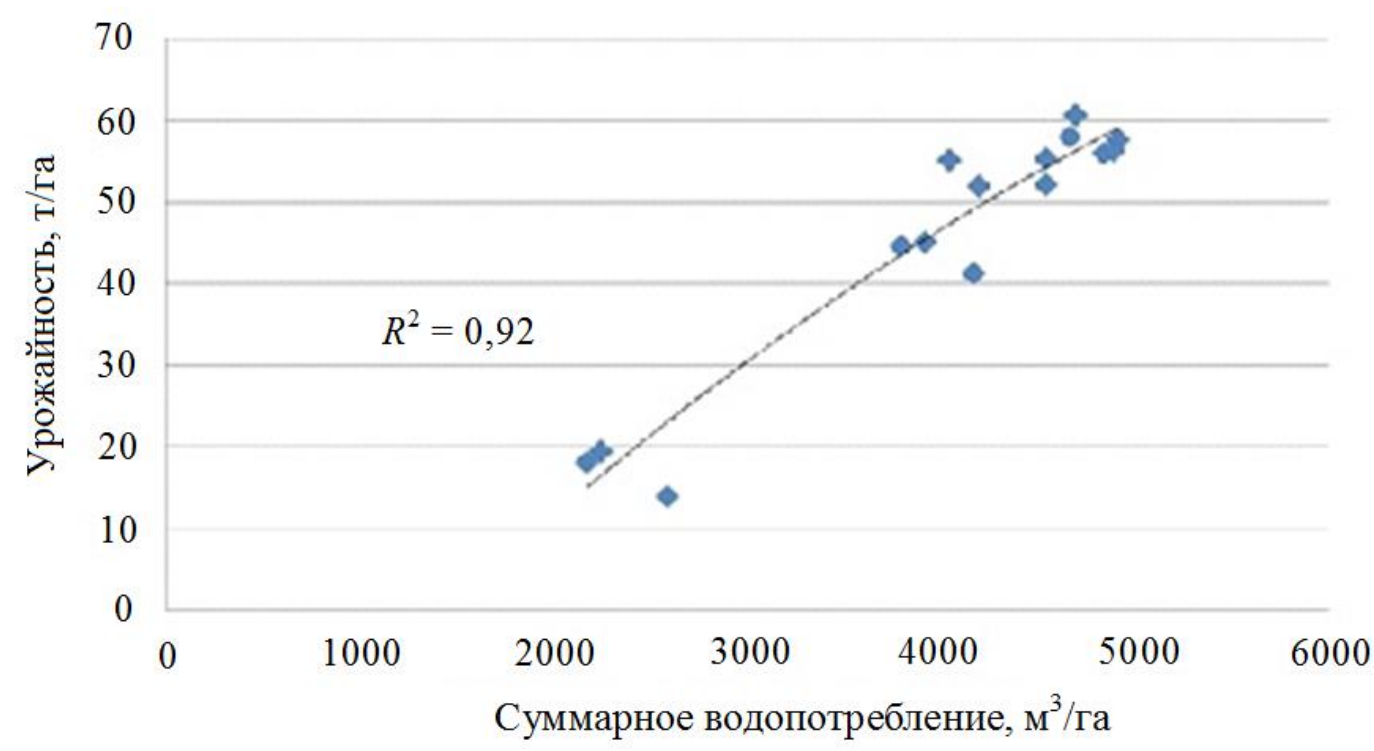

Рисунок 2 - Взаимосвязь между урожайностью и суммарным водопотреблением картофеля весеннего срока посадки на черноземах, 2015-2017 гг.

\section{Выводы}

1 Установлено, что снижение водообеспеченности создает менее благоприятные условия для растений и приводит к сокращению вегетационного периода картофеля на 4-6 сут. Изменяются также морфологические показатели, такие как высота растений и площадь листовой поверхности. Наибольшими высота растений картофеля (0,74 м), площадь листовой поверхности и прирост надземной массы были в вариантах 1 и 2.

2 Урожайность товарных клубней в среднем за годы исследований была более высокой $(58,8$ т/га) в контрольном варианте 1 . Уменьшение оросительной нормы на $20 \%$ в варианте 3 и на $40 \%$ в варианте 4 привело к снижению урожайности до 53,1 и 43,7 т/га соответственно, но при снижении оросительной нормы на 20 \% в варианте 3 урожайность снижается только на 9,7 \%, а при уменьшении оросительной нормы на 40 \% наблюдалось снижение урожайности на 25,6 \%, т. е. можно говорить об экономии 
водных ресурсов на единицу продукции в вариантах 3 и 4, что подтверждается данными о водопотреблении картофельного поля.

3 Водопотребление изменяется в зависимости от водообеспеченности по годам, составляя в среднем за 2015-2017 гг. от 2332 м³/га в вариан-

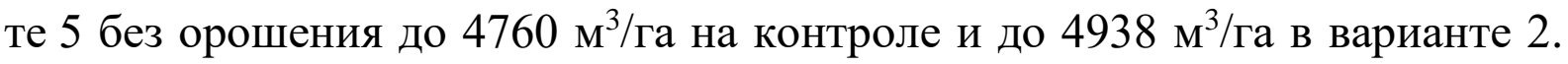
Оросительная норма при этом увеличивалась с $1800 \mathrm{~m}^{3 /}$ га в варианте 4 до $3000 \mathrm{~m}^{3} /$ га на контроле и до $3600 \mathrm{~m}^{3} /$ га в варианте 2. При уменьшении водообеспеченности сокращается период вегетации, что влияет на среднесуточное водопотребление, которое изменяется соответственно с 32,8 м²/га в варианте 5 без орошения до 62,5 м³/га в варианте 2 с наибольшей водообеспеченностью.

4 Более высокая эффективность использования воды на формирование единицы урожая, выраженная через коэффициент водопотребления, отмечена в варианте $3\left(80,3 \mathrm{~m}^{3} / \mathrm{T}\right)$ при уменьшении оросительной нормы на $20 \%$, на контроле показатель возрастал до 81,0 м³/т, а в вариантах 2 и 4 увеличился и составил по 88,3 м³/т. Эффективность использования водных ресурсов, выраженная производством клубней на $1000 \mathrm{M}^{3}$ оросительной воды, была более высокой в вариантах 4 и 3 (соответственно 24,3 и 22,1 т) при сокращении оросительной нормы на 40 и $20 \%$ соответственно. В контрольном варианте 1 этот показатель составил 19,6 т и наименьшим (15,5 т) был в варианте 2 с увеличенной на 20 \% оросительной нормой. Поэтому в условиях острого дефицита водных ресурсов для получения большей отдачи от используемой оросительной воды возможно снижение оросительной нормы на $20 \%$, при этом урожайность снижается на 9,7 \%, но повышается эффективность использования оросительной воды.

\section{Список использованных источников}

1 Стратегия инновационного развития мелиоративного комплекса России на период 2012-2020 годы / В. Н. Щедрин, Г. Т. Балакай, А. И. Перелыгин, Л. М. Докучаева, Т. П. Андреева, Н. И. Балакай; ФГНУ «РосНИИПМ». - Новочеркасск, 2011. - 48 с. Деп. в ВИНИТИ 19.07.11, № 348-В2011.

2 Ольгаренко, Г. В. Концепция государственной программы «Восстановление и 
развитие мелиоративного комплекса Российской Федерации на период 2020-2030 годов» / Г. В. Ольгаренко, С. М. Васильев, Г. Т. Балакай. - Новочеркасск: РосНИИПМ, 2019. - $128 \mathrm{c}$.

3 Балакай, Г. Т. Развитие мелиорации - основа стабилизации производства сельскохозяйственной продукции в России / Г. Т. Балакай // Научный журнал Российского НИИ проблем мелиорации [Электронный ресурс]. - 2011. - № 2(02). - С. 1-9. - Режим доступа: http:rosniipm-sm.ru/article?n=432.

4 Проблемы и перспективы использования водных ресурсов в агропромышленном комплексе России: монография / сост.: В. Н. Щедрин, Ю. М. Косиченко, С. М. Васильев, Г. Т. Балакай, Г. А. Сенчуков, Е. И. Шкуланов; под общ. ред. В. Н. Щедрина; ФГНУ ЦНТИ «Мелиоводинформ». - М., 2009. - 342 с.

5 Система ведения агропромышленного производства Волгоградской области на 1996-2010 гг. / И. П. Шабунин [и др.]. - Волгоград: Ком. по печати, 1997. - 208 с.

6 Обоснование эффективности планирования технологических процессов водопользования и оперативное управление водораспределением на базе использования метода Монте-Карло / В. И. Ольгаренко, И. Ф. Юрченко, И. В. Ольгаренко, Г. Г. Костюнин, М. С. Эфендиев, В. Иг. Ольгаренко // Научный журнал Российского НИИ проблем мелиорации [Электронный ресурс]. - 2018. - № 1(29). - С. 49-66. - Режим доступа: http:www.rosniipm-sm.ru/archive?n=526\&id=530.

7 Полуэктов, Е. В. Агроландшафты юга России и их классификация по типам / Е. В. Полуэктов, Г. Т. Балакай, Н. И. Балакай // Пути повышения эффективности орошаемого земледелия: сб. ст. / ФГНУ «РосНИИПМ». - Новочеркасск: Геликон, 2006. Вып. 35. - С. 43-48.

8 Способы мелиорации орошаемых солонцовых почв: науч. обзор / Г. Т. Балакай, Л. М. Докучаева, Р. Е. Юркова, Т. В. Усанина, Т. П. Андреева, Е. В. Долина, Э. Н. Стратинская, О. Ю. Шалашова; ФГНУ «РосНИИПМ». - Новочеркасск, 2011. - 73 с. - Деп. в ВИНИТИ 23.05.11, № 245-В2011.

9 Мелихов, В. В. О новой концепции комплексных мелиораций сельскохозяйственных земель России / В. В. Мелихов, А. А. Новиков, В. А. Шевченко // Проблемы развития сельскохозяйственных мелиораций и водохозяйственного комплекса на базе цифровых технологий: материалы междунар. юбилейн. науч.-практ. конф., 23-24 окт. 2019 г. - М.: Изд-во ВНИИГиМ, 2019. - Т. 1. - С. 196-201.

10 Новиков, А. А. Влияние способов полива и окучивания на режим орошения картофеля / А. А. Новиков // Известия Нижневолжского агроуниверситетского комплекса: наука и высшее профессиональное образование. - 2019. - № 2(54). - С. 145-153.

11 Доспехов, Б. А. Методика полевого опыта / Б. А. Доспехов. - М.: Агропромиздат, 1985. - $352 \mathrm{c}$.

12 Плешаков, В. Н. Методика полевого опыта в условиях орошения / В. Н. Плешаков. - Волгоград: ВНИИОЗ, 1983. - 148 с.

13 Мелихов, В. В. Эффективность удобрения раннего картофеля при капельном орошении / В. В. Мелихов, А. А. Новиков // Плодородие. - 2011. - № 5(62). - С. 25-26.

14 Новиков, А. А. Влияние способов полива и окучивания картофеля на структурное состояние почвы / А. А. Новиков // Агрофизика. - 2019. - № 3. - С. 14-19.

\section{References}

1 Shchedrin V.N., Balakai G.T., Perelygin A.I., Dokuchaeva L.M., Andreeva T.P., Balakai N.I., 2011. Strategiya innovatsionnogo razvitiya meliorativnogo kompleksa Rossii na period 2012-2020 gody [Innovative Development Strategy of Russian Reclamation Complex for the Period 2012-2020]. Novocherkassk, 48 p., deposited in VINITI on 19.07.2011, no. 348-V2011. (In Russian).

2 Olgarenko G.V., Vasiliev S.M., Balakai G.T., 2019. Kontseptsiya gosudarstvennoy 
programmy "Vosstanovlenie i razvitie meliorativnogo kompleksa Rossiyskoy Federatsii na period 2020-2030 godov" [Concept of the State Program "Restoration and Development of Land Reclamation Complex of the Russian Federation for the Period 2020-2030"]. Novocherkassk, RosNIIPM, 128 p. (In Russian).

3 Balakai G.T., 2011. [Development of land reclamation - the basis for stabilizing agricultural production in Russia]. Nauchnyy Zhurnal Rossiysskogo NII Problem Melioratsii, no. 2(02), pp. 1-9, available: http:rosniipm-sm.ru/article?n=432. (In Russian).

4 Shchedrin V.N., Kosichenko Yu.M., Vasiliev S.M., Balakai G.T., Senchukov G.A., Shkulanov E.I., 2009. Problemy $i$ perspektivy ispol'zovaniya vodnykh resursov v agropromyshlennom komplekse Rossii: monografiya [Problems and Prospects for Water Resources Use in Agricultural Sector of Russia: monograph]. Moscow, Meliovodinform Publ., 342 p. (In Russian).

5 Shabunin I.P. [et al.], 1997. Sistema vedeniya agropromyshlennogo proizvodstva Volgogradskoy oblasti na 1996-2010 gg. [The System of Agricultural Production of Volgograd Region for 1996-2010]. Volgograd, Printing Committee Publ., 208 p. (In Russian).

6 Olgarenko V.I., Yurchenko I.F., Olgarenko I.V., Kostyunin G.G., Efendiev M.S., Olgarenko V.Ig., 2018. [Planning effectiveness substantiation of technological processes of water use and operating control of water distribution using the Monte Carlo method]. Nauchnyy Zhurnal Rossiysskogo NII Problem Melioratsii, no. 1(29), pp.49-66, available: http:www.rosniipm-sm.ru/archive?n=526\&id=530. (In Russian).

7 Poluektov E.V., Balakai G.T., Balakai N.I., 2006. Agrolandshafty yuga Rossii i ikh klassifikatsiya po tipam [Agrolandscapes of the south of Russia and their classification by types]. Puti povysheniya effektivnosty oroshaemogo zemledeliya: sbornik statey RosNIIPM [Ways of Increasing the Efficiency of Irrigated Agriculture: Collection of Articles of Russian Scientific Research Institute of Land Improvement Problems]. Novocherkassk, Helikon Publ., iss. 35, pp. 43-48. (In Russian).

8 Balakai G.T., Dokuchaev L.M., Yurkova R.E., Usanina T.V., Andreeva T.P., Dolina E.V., Stratinskaya E.N., Shalashova O.Yu., 2011. Sposoby melioratsii oroshaemykh solontsovykh pochv: nauchnyy obzor [Methods of Reclamation of Irrigated Saline Soils: Scientific Review]. Novocherkassk, 73 p., deposited in VINITI 23.05.2011, no. 245-V2011. (In Russian).

9 Melikhov V.V., Novikov A.A., Shevchenko V.A., 2019. O novoy kontseptsii kompleksnykh melioratsiy sel'skokhozyaystvennykh zemel' Rossii [On a new concept of complex land reclamation of agricultural lands in Russia]. Problemy razvitiya sel'skokhozyaystvennykh melioratsiy $i$ vodokhozyaystvennogo kompleksa na baze tsifrovykh tekhnologiy: materialy mezhdunarodnoy yubileynoy nauchno-prakticheskoy konferentsii [Problems of Development of Agricultural Land Reclamation and Water Management Complex Based on Digital Technologies: Proc. International Anniversary Scientific-Practical Conference]. Moscow, VNIIGiM Publ., vol. 1, pp. 196-201. (In Russian).

10 Novikov A.A., 2019. Vliyanie sposobov poliva i okuchivaniya na rezhim orosheniya kartofelya [Influence of irrigation and hilling methods on potato irrigation regime]. Izvestiya Nizhnevolzhskogo agrouniversitetskogo kompleksa: nauka $i$ vysshee professional'noe obrazovanie [Bull. of the Lower Volga Agro-University Complex: Science and Higher Professional Education], no. 2(54), pp. 145-153. (In Russian).

11 Dospekhov B.A., 1985. Metodika polevogo opyta [Methodology of Field Experience]. Moscow, Agropromizdat Publ., 352 p. (In Russian).

12 Pleshakov V.N., 1983. Metodika polevogo opyta $v$ usloviyakh orosheniya [Field Experiment Methodology under Irrigation]. Volgograd, VNIIOZ, 148 p. (In Russian).

13 Melikhov V.V., Novikov A.A., 2011. Effektivnost' udobreniya rannego kartofelya pri kapel'nom oroshenii [Efficiency of early potato fertilization under drip irrigation]. Plodorodie [Fertility], no. 5(62), pp. 25-26. (In Russian). 
Научный журнал Российского НИИ проблем мелиорации, № 3(39), 2020 г., [38-51]

14 Novikov A.A., 2019. Vliyanie sposobov poliva i okuchivaniya kartofelya na strukturnoe sostoyanie pochvy [Influence of methods of irrigation and hilling of potatoes on the structural state of soil]. Agrofizika [Agrophysics], no. 3, pp. 14-19. (In Russian).

\section{Новиков Алексей Андреевич}

Ученая степень: кандидат сельскохозяйственных наук

Должность: заместитель директора по научной работе и инновационному развитию

Место работы: федеральное государственное бюджетное научное учреждение «Всероссийский научно-исследовательский институт орошаемого земледелия»

Адрес организации: ул. Тимирязева, д. 9, г. Волгоград, Российская Федерация, 400002

E-mail: vniioz@yandex.ru

\section{Novikov Aleksey Andreyevich}

Degree: Candidate of Agricultural Sciences

Position: Deputy Director for Research and Innovation Development

Affiliation: All-Russian Research Institute of Irrigated Agriculture

Affiliation address: st. Timiryazeva, 9, Volgograd, Russian Federation, 400002

E-mail: vniioz@yandex.ru 